\title{
Humanização, Cuidado e Os Aspectos Éticos da Contenção Mecânica: um Relato de Experiência
}

\author{
Leal, Leidiane Maciel; Silva, Isabelly Regina Paiva da; Sousa, Brenda Mayara da \\ Rocha de; Castro, Luna Carolina Cardoso; Santos, Brena Maués de Souza \\ Universidade Estadual do Pará/Hospital de Clínicas Gaspar Vianna — leidi_leal@yahoo.com.br
}

\begin{abstract}
INTRODUÇÃO: Os aspectos éticos relacionados ao tratamento a pessoa em sofrimento psíquico suscitam discussões e contradições relacionadas à humanização, principalmente durante a execução de procedimentos como a contenção mecânica. Historicamente os portadores de sofrimento psíquico eram trancafiados nos hospícios, sem tratamento digno e humano, destituídos de seus direitos. a assistência psiquiátrica tinha caráter repressivo, segregador e cruel, o tratamento consistia em: banhos frios, chicotadas, sangrias, lobotomia e eletroconvulsoterapia. Através da Reforma Psiquiátrica, com a Lei 10.216 (dispondo sobre proteção e direitos das pessoas portadoras de transtornos mentais), associada à Política Nacional de Humanização como estratégia para um cuidado baseado na ética, o doente mental passou a ser considerado sujeito de direitos, sendo tratado dignamente, com humanização, visando a conquista de sua cidadania e autonomia. Este trabalho vem discorrer sobre a humanização durante a contenção mecânica e as experiências vivenciadas durante esse procedimento em Hospital Geral Público, por período de seis meses, através da Residência Multiprofissional em Saúde relacionando questões éticas ao cuidado com portador de sofrimento psíquico. OBJETIVOS: Discutir a prática da contenção mecânica sob a luz da humanização, relacionando-a com as experiências vivenciadas pelas residentes em Hospital Geral Público com leitos psiquiátricos. METODOLOGIA: Observação direta e ativa dos pacientes e profissionais durante a contenção, verificando se as técnicas estabelecidas em protocolo assistencial eram utilizadas. a contenção mecânica deve ocorrer quando o paciente apresenta sintomas psicóticos de agressividade, APM e ideação e/ou tentativa de suicídio, com o intuito de assegurar sua integridade física e de outrem. Rotineiramente os profissionais imobilizavam os pacientes, através da contenção física, como método de punição, sem a utilização prévia das contenções verbal e química. como residentes do serviço, realizávamos orientações junto ao paciente sobre a necessidade do procedimento, para propiciar a compreensão sobre a conduta realizada, dos motivos que ocasionaram a mesma e o registro em prontuário dos respectivos pacientes. a partir disto visando à reflexão do processo, realizamos o levantamento bibliográfico. RESULTADOS: Foi verificada que a atuação dos profissionais, ocorre sem supervisão de um profissional de nível superior ou equipe multiprofissional, com inabilidade na realização gerando acidentes de trabalho; de forma coercitiva, sem fins terapêuticos contradizendo os princípios da PNH em Saúde Mental. CONCLUSÃO: por meio da Lei dos direitos humanos de 1998, todo tratamento acompanhado de sofrimento físico ou psíquico é caracterizado como desumano logo, necessita-se de estratégias para garantir uma assistência humanizada, deixando de gerar medo, insegurança e humilhação nos pacientes durante internação psiquiátrica.
\end{abstract}

Leal, Leidiane Maciel; Silva, Isabelly Regina Paiva da; Sousa, Brenda Mayara da Rocha de; Castro, Luna Carolina Cardoso; Santos, Brena Maués de Souza. Humanização, Cuidado e Os Aspectos Éticos da Contenção Mecânica: um Relato de Experiência. In: Anais do Congresso Internacional de Humanidades \& Humanização em Saúde [= Blucher Medical Proceedings, num.2, vol.1]. São Paulo: Editora Blucher, 2014. ISSN 2357-7282

DOI 10.5151/medpro-cihhs-10427 